\title{
Screening and identification of abiotic stress-responsive efficient antifungal Pseudomonas spp. from rice rhizospheric soil
}

\author{
ARUN KARNWAL \\ School of Bioengineering and Biosciences, Lovely Professional University, Punjab, India
}

\begin{abstract}
Plant growth-promoting rhizobacteria (PGPR) are a collection of microorganisms often used to support and promote plant development and combat plant infectious diseases with various biological control methods. The most significant restricting factors for agricultural productivity worldwide are abiotic constraints. In the present study, seven bacterial isolates from the rice rhizosphere were selected for detailed tests based on results obtained in experiments determining the ACC deaminase synthesis and drought tolerance at - $0.30 \mathrm{MPa}$ PEG level. Screening results of the stress tolerance analysis of the seven isolates for elevated temperature $\left(50^{\circ} \mathrm{C}\right)$, alkalinity $(10 \%$ $\mathrm{NaCl}$ ), and drought $(-1.2 \mathrm{MPa})$ showed that abiotic stress resistance was less prevalent in DRO2, DRO13, and DRO43 isolates than in DRO17, DRO28, DRO35, and DRO51 isolates. During the study, it was observed that DRO17, DRO28, and DR051 tended to maintain similar cell density at -0.73 MPa PEG level, as observed at $-0.30 \mathrm{MPa}$ stress condition. No bacterial growth was observed at higher PEG level ( $-1.12 \mathrm{MPa})$ for any bacterial isolate. Four strains of Pseudomonas (DRO17, DRO28, DRO35, and DR051) exhibited salinity and temperature tolerance. Antifungal screening using the bangle method showed that DRO35 was highly antagonistic towards Rhizoctonia solani 4633, followed by Fusarium moniliforme 4223, with an inhibition of $64.3 \%$ and $48 \%$, respectively. The DRO28 isolate exhibited 72.5\% growth inhibition for Fusarium moniliforme 4223, while the DRO51 isolate showed 38.2\% growth inhibition for Bipolaris hawaiiensis 2445. DRO17 reduced the growth of Rhizoctonia solani 4633, and Curvularia lunata 350 by $36 \%$ and $31 \%$, respectively. In conclusion, the screening of bacterial strains with promising stress tolerance and antifungal characteristics could support farmers to achieve the required positive outcomes in the agriculture field.
\end{abstract}

Key words: abiotic stress, ACC deaminase, antifungal, biofertilizer, Pseudomonas, rice rhizosphere

\section{Introduction}

Plants experience various abiotic and biotic stresses, and in order to grow and flourish, they have developed various mechanisms that help them to combat unfavourable conditions. According to world estimates, an average of $50 \%$ yield losses of crops is due to abiotic factors such as high temperature (20\%), low temperature $(7 \%)$, salinity $(10 \%)$, drought $(9 \%)$, and other forms of stresses (4\%) (Kajla et al., 2015; Kumar and Verma, 2018; Karnwal, 2020). These stresses alone or combined can pose seriously affect grain quality and crop production (Xu et al., 2018), for example, high temperature ( $42 \%$ loss in maize, $31 \%$ in wheat, and $50 \%$ in rice) and drought stress $(63-87 \%$ loss in maize, $57 \%$ in wheat, $53-92 \%$ in rice, $45-69 \%$ in chickpea, and $46-71 \%$ in soybean). Plant mechanisms to regulate abiotic stresses are complicated and involve modulation of gene expression (Saleem et al., 2007; Jahromi et al., 2008). These genes, whether directly through chaperones and osmotic regulators (Denslow et al., 2007) or indirectly through transcription regulation and signalling (Rueda-Puente et al., 2010), actively promote stress regulation (Praveen Kumar et al., 2014). Moreover, some molecules, including single-stranded RNA (ssRNA), peptides, and metabolites, serve as physiological triggers to overcome stress during plant development under stressful conditions

\footnotetext{
* Corresponding author: School of Bioengineering and Biosciences, Lovely Professional University, Jalandhar-Delhi G.T. Road, National Highway 1, Phagwara, Punjab 144411, India; e-mail: arunkarnwal@gmail.com
} 
(Amna et al., 2020). Multiple abiotic stress signalling molecules are reported to be controlled either by PGRs (plant growth regulators) or by phytohormones (Badr et al., 2020) such as auxins, cytokinins, gibberellin, abscisic acid (ABA), brassinosteroids, salicylic acid, jasmonates and ethylene, which are actively or passively associated with a wide variety of abiotic stress management (Fahad etal., 2015; Soda etal., 2016; Tiwari etal., 2017). ABA plays a critical role in abiotic stress responses. It affects many genes that act as mediators in systemic stress regulation with various functions, i.e. decreasing the effect of stress conditions such as drought, extreme temperature, and high salinity, seed dormancy and germination, and modulation of root architecture, leaf senescence, and stomata regulation (Garg et al., 2002; Lee et al., 2006; Mhamdi et al., 2015).

Interestingly, many plant growth- promoting rhizobacteria (PGPR) are known to produce plant hormones such as auxins, gibberellic acid, and cytokine and inhibit ethylene synthesis during plant development. PGPR are a community of microorganisms that can boost plant development and yield (Singh et al., 2015; Heydarian et al., 2016). Although the majority of PGPR are root colonizers, they provide a positive systemic effect on the entire plant (Amna et al., 2020). The use of such valuable microorganisms (Pseudomonas, Azotobacter, Azospirillum, Bacillus, Rhizobium, and Rhodopseudomonas) is considered as one of the most successful practices in securing crop management (Karnwal, 2009; Fahad et al., 2015; Lee et al., 2016). Moreover, a combination of PGPR strains can enhance abiotic stress resistance of plants by priming of induced systemic tolerance (IST), e.g. salt, drought, heat, and cold stress tolerance (Kumar and Verma, 2018). The priming phenomena involving PGPR appear to be active in many farming crops tomato, broad bean, soybean, lettuce, chickpea, wheat, maize, sugar beet, strawberry, apple, and grapes (Rojas-Tapias et al., 2012; Borges et al., 2014; Mahmood et al., 2016).

Some PGPR synthesize antifungal metabolites, e.g. $P$. fluorescens produces 2,4-diacetyl phloroglucinol, which inhibits the growth of phytopathogenic fungi (Akter et al., 2016). Pseudomonas stutzeri produces extracellular chitinase and laminarinase, which lyses the mycelia of Fusarium solani (Rojas-Solís et al., 2018). Pseudomonas possesses many traits that make them well suited as biocontrol and growth-promoting agents. These traits include the ability to 1 ) grow rapidly in vitro and to be mass-produced; 2) rapidly utilize seed and root exudates; 3) colonize and multiply in the rhizosphere and spermosphere environments and in the interior of the plant; 4) produce a broad spectrum of bioactive metabolites (i.e. antibiotics, siderophores, volatiles, and growth-promoting substances); 5) compete aggressively with other microorganisms; and 6) adapt to environmental stresses (Korejo et al., 2017; Andreolli et al., 2019; Wang et al., 2020).

The genera Bipolaris, Curvularia, Fusarium, Alternaria, and Sclerotium include important fungal plant pathogens with worldwide distribution (Korejo et al., 2017). Members of these genera are commonly associated with leaf spots, leaf blights, melting outs, root rots, foot rots, wilting, crown rots, brown lesions, necrotic spots on leaves, and other disease symptoms mainly in high-value field crops, including cauliflower, cucurbits, onions, peanut, peppers, broccoli, carrot, potato, rice, maize, wheat, and sorghum and on various other host plants (Jadhav et al., 2017). Bipolaris spp. (B. sorokiniana and $B$. hawaiiensis) are common root rot and leaf spot pathogens of wheat and barley and were declared as the most economically important foliar pathogens of wheat in warm regions (Kekuda et al., 2016). The fungal genus Curvularia is associated with several diseases in plants, commonly producing foliar spots in forage grasses (Shirsath et al., 2018). The species of Curvularia genus (i.e., $C$. trifolii, $C$. protuberata, $C$. eragrostidis, $C$. intermedia, $C$. penniseti, $C$. lunata, $C$. senegalense, and C. geniculate) consist of saprophytes, endophytes, and pathogens that cause crop loss in sugarcane, wheat, rice, millet, and maize (Jadhav et al., 2017). Fusarium species cause dry rot in potato, wilting and decline in bean or pea, crown rot and head blight in wheat, and bakanae disease in rice, which result in yield losses in most crops (Khan et al., 2017). Several species of Fusarium produce mycotoxins that cause severe animal diseases such as feed refusal syndrome, moldy sweet potato toxicity, and bean hull poisoning (Selikhovkin et al., 2018). Alternaria spp. are also well known as post harvest pathogens. A. triticina is one of the several species in the genus that have been isolated from wheat leaves; it is demonstrated to be pathogenic, whereas other species appear to be primarily saprophytes (Grebenikova et al., 2018). The leaf blight disease caused by $A$. triticina is a serious problem for susceptible cultivars of durum (Triticum turgidum subsp. Durum) and bread wheat 
(Triticum aestivum) in India (De Vita and Taranto, 2019). Sclerotium is a fungal pathogen that can cause considerable crop damage, but it is more common in warmer climates $\left(8-40^{\circ} \mathrm{C}\right)$ (Jadhav et al., 2017). The most common fungal species that attack greenhouse crops are Sclerotium rolfsii and Sclerotium oryzae. Sclerotium spp. hence, they commonly infect beans, beets, carrots, corn, cucurbits, onions, peanut, peppers, potatoes, rice, tomatoes, watermelon, and wheat; they can also infect greenhouse crops such as chrysanthemum, iris, lilies, narcissus, and zinnias (Volpiano et al., 2018).

The present research was therefore conducted to identify effective Pseudomonas strains from rice rhizosphere screened from various agriculture farms of Dehradun to analyse their ability to reduce the effect of abiotic stress, including high temperature, salinity, and drought, in crop plants and to determine their antagonistic activity against fungal phytopathogens.

\section{Materials and methods}

\section{Sampling and isolation of root-associated Pseudomonas spp.}

Forty healthy rice crop samples were collected in November 2019 from Dehradun $\left(30^{\circ} 24^{\prime} 57.9^{\prime \prime} \mathrm{N}, 77^{\circ} 58^{\prime}\right.$ $\left.4.1^{\prime \prime} \mathrm{E}\right)$ situated in Uttarakhand, India. The city has an average annual rainfall ranging from 1896 to $2073.3 \mathrm{~mm}$ (8.6 $\mathrm{mm}$ in November) with a humid subtropical climate. The agriculture soil was listed as alluvial type and brown. The main physiochemical attributes of the soil were as follows: $\mathrm{pH}$ : 5.6, moisture content: $47.68 \%$, total alkalinity: $1.67 \mathrm{mg} / \mathrm{gm}$, total organic carbon content: $3.04 \%$, total nitrogen content: $0.628 \%$, available phosphorus content: $12.650 \mu \mathrm{g} / \mathrm{gm}$, available potassium content: $0.0282 \mathrm{mg} / \mathrm{gm}$, conductivity: $0.754 \mu \mathrm{s} / \mathrm{cm}$, phosphorus content: $23 \mathrm{~kg} / \mathrm{ha}$, nitrogen: $406 \mathrm{~kg} / \mathrm{ha}$, and potassium: $21 \mathrm{~kg} / \mathrm{ha}$. At the time of sampling, humidity (H\%) of the soil was $7.4 \%$. Each sample of the rice crop was immediately stored in a clean and sterilized polythene ziplocked bag and brought to the institute research laboratory (Bhojia Institute of Life Sciences, Baddi, Himachal Pradesh, India) and stored at $4{ }^{\circ} \mathrm{C}$ until processing.

Ten grams of aseptically segregated root pieces of each rice crop sample were transferred in the Erlenmeyer flasks containing $90 \mathrm{ml}$ of $0.85 \%$ normal sterile saline and gently stirred for $30 \mathrm{~min}$ to remove adhered soil available on root segments. This worked as a stock suspension for bacteria isolation. A series (up to 6) of 10 -fold dilutions of stock solution was prepared, and $0.1 \mathrm{ml}$ aliquots were spread over King's B agar plates (protease peptone $20 \mathrm{~g} / \mathrm{l}$, glycerol $10 \mathrm{ml}$, dipotassium hydrogen phosphate $1.5 \mathrm{~g} / \mathrm{l}$, magnesium sulphate heptahydrate $1.5 \mathrm{~g} / \mathrm{l}$, agar $20 \mathrm{~g} / \mathrm{l}, \mathrm{pH} 7.2 \pm 0.2$ ) in duplicates (Paul et al., 2006). Sample-inoculated plates were cultivated at $28^{\circ} \mathrm{C}$ until the bacterial growth was observed. For further purification and studies, independent bacterial colonies were selected and transferred onto freshly prepared King's B plates.

\section{Screening for ACC (1-aminocyclopropane-1-carboxylate) deaminase activity}

The potential of the bacterial isolates (DRO1 to DRO56) to synthesize 1-aminocyclopropane-1-carboxylate (ACC) deaminase was screened qualitatively based on their ability to use ACC as a sole source of nitrogen. Isolates were inoculated on the $\mathrm{DF}$ salts minimum agar medium added with $3 \mathrm{mM} \mathrm{ACC}$ (nitrogen source) instead of $\left(\mathrm{NH}_{4}\right)_{2} \mathrm{SO}_{4}$ as suggested by Dworkin and Foster (1958). The DF agar plates were incubated at $28 \pm 2^{\circ} \mathrm{C}$ for $48 \mathrm{~h}$ in a BOD incubator. ACC deaminase production was determined by successful bacterial growth after $48 \mathrm{~h}$ under nonstress or drought stress conditions $(-0.30 \mathrm{MPa})$.

ACC deaminase activity of seven bacterial isolates (which could tolerate $-0.30 \mathrm{MPa}$ drought stress) was examined quantitatively using the spectrophotometric method at $540 \mathrm{~nm}$ in terms of the released $\alpha$-ketobutyrate as described by Honma and Shimomura (1978). The released $\alpha$-ketobutyrate amount was measured by comparing with the $\alpha$-ketobutyrate standard curve (from 0.1 to $1.0 \mu \mathrm{mol})$. The protein concentration was estimated following the Bradford method (Bradford, 1976). One unit of ACC deaminase activity was expressed as the amount of $\alpha$-ketobutyrate released in nmol per milligram of cellular protein per hour.

\section{Screening of isolates for abiotic stress tolerance and antifungal activity}

Seven ACC deaminase producing bacterial isolates (tolerating drought stress at $-0.30 \mathrm{Mpa}$ ) were further studied to determine their survival under other abiotic stresses such as elevated temperature $\left(40\right.$ to $\left.50^{\circ} \mathrm{C}\right)$, salinity (5\%-0.86 M and 7\%-1.2 M NaCl), and drought $(-0.30,-0.73$, and $-1.12 \mathrm{MPa})$ in trypticase soy broth 
(TSB) (pancreatic digest of casein $17 \mathrm{~g} / \mathrm{l}$, papaic digest of soybean meal $3 \mathrm{~g} / \mathrm{l}$, sodium chloride $5 \mathrm{~g} / \mathrm{l}$, dextrose $2.5 \mathrm{~g} / 1$, dibasic potassium phosphate $2.5 \mathrm{~g} / 1, \mathrm{pH} 7.3 \pm 0.2$ ) as described by Saleem et al. (2007).

\section{High temperature tolerance}

Ten millilitres of TSB was transferred into $30 \mathrm{ml}$ screwcapped tubes and autoclaved. Each time, freshly grown bacterial culture with $1 \mathrm{McF}$ arland $\left(2.8 \times 10^{8} \mathrm{CFU} / \mathrm{ml}\right)$ cell density was used as the initial inoculum for analysis. The temperature effect was studied at 45 and $50^{\circ} \mathrm{C}$ incubation temperature by inoculating the bacterial isolates in trypticase soya broth for $48 \mathrm{~h}$. The OD of culture was recorded at $600 \mathrm{~nm}$.

\section{Salinity tolerance}

Trypticase soy broth $(10 \mathrm{ml})$ amended with either $5 \%$ $(0.86 \mathrm{M})$ or $7 \%(1.2 \mathrm{M}) \mathrm{NaCl}$ was used for salinity tolerance analysis. One hundred microlitres of fresh bacterial cultures (1 McFarland) in the exponential growth phase was used as the initial inoculum. The tubes were incubated at $28 \pm 2{ }^{\circ} \mathrm{C}$ in a BOD incubator shaker (120 rpm). The bacterial cell density was measured at $600 \mathrm{~nm}$ after every 3 by using a spectrophotometer. Growth medium without bacterial inoculation was used as control.

\section{Drought tolerance}

Five hundred millilitres of trypticase soya broth of differing water potential $(-0.30,-0.73$, and $-1.12 \mathrm{MPa})$ was prepared by adding the appropriate concentrations of PEG 6000 (Rehman and Nautiyal, 2002; GontiaMishra et al., 2016). The liquid nutrient medium was dispensed and autoclaved in $30 \mathrm{ml}$ screwed-capped tubes. Freshly grown $1 \mathrm{ml}$ of bacterial cultures (1 McFarland) in the exponential growth phase were used as the initial inoculum. The bacteria-inoculated tubes were incubated on a shaker $(120 \mathrm{rpm})$ at $28 \pm 2^{\circ} \mathrm{C}$, and bacterial cell density was measured after every $3 \mathrm{~h}$ at $600 \mathrm{~nm}$ using a spectrophotometer. Growth medium without bacterial inoculation was used as control.

\section{Screening for antagonistic activity of abiotic stress-tolerant bacterial isolates against fungal pathogens of rice}

The four abiotic stress-tolerant (temperature, salinity, and drought) bacterial isolates were screened for their antagonistic activity against six fungal phytopathogens. The antagonistic activity of all Pseudomonas spp. (see biochemical characterization and molecular identification of bacterial isolates sections) was assessed on maltose dextrose agar against major rice pathogens collected from ITCC culture collection of IARI, New Delhi, namely, Bipolaris hawaiiensis 2445, Rhizoctonia solani 4633, Curvularia lunata 350, Fusarium moniliforme 4223, Alternaria padwickii 4122, and Sclerotium oryzae 3821. The antagonistic activity of bacterial isolates for fungal pathogens was determined using dual culture approach (Sukmawati et al., 2020; Patel et al., 2018). A 5-mm diameter mycelial disc of the fungal phytopathogen and the tested bacterial isolates were inoculated on Petri plates containing potato dextrose agar medium (dextrose $20 \mathrm{gm}$, potato starch $4 \mathrm{gm}$, agar $15 \mathrm{gm}$, distilled water 11 ) in opposite direction at an equal distance from the periphery. Each individual combination (pathogen + bacteria) was examined in triplicates. The Petri plates inoculated with a 5-mm diameter mycelial disc of fungal phytopathogen alone was used as a control.

Bacterial isolates successfully inhibiting the growth of all fungal pathogens during dual culture examination were further examined for their potential to inhibit fungal growth on maltose-dextrose agar Petri plates (Praveen Kumar et al., 2014). In this test, a $70 \mathrm{~mm}$ diameter bangle was submerged into the bacterial cultures for 2 min and placed on Petri plates containing a solidified maltose-dextrose agar medium. The bacterial cultures were grown in King's B broth. Next, 5-mm-thick fungal pathogen discs were cut from the actively growing fungal cultures with a sterilized cork borer and placed in the centre of the bangle. Control plates contained only the tested fungi. The periphery of the Petri plates was sealed entirely with paraffin film and placed in an incubator at $28^{\circ} \mathrm{C}$ for 7 days. Radial fungal development was measured, and the percentage of inhibition was determined. The antagonistic effect was measured as the percentage of fungal development inhibition.

\section{Biochemical characterization of bacterial isolates}

Fourstress-tolerant bacterial isolates (DRO17, DRO28, DRO35, and DRO51) were identified microscopically and biochemically as described in Bergey's Manual of Systematic Bacteriology (Krieg and Holt, 1984). The isolates were examined for shape, Gram staining, motility, urease production, endospore formation, catalase test, lipolysis activity, starch hydrolysis, oxidase test, gelatine 
liquefaction, citrate utilization, casein hydrolysis, oxidation-fermentation test, indole production, sugar fermentation, $\mathrm{H}_{2} \mathrm{~S}$ production, and $\mathrm{HCN}$ production (Karnwal, 2009).

\section{Molecular identification of the bacterial isolates}

The four stress-tolerant bacterial isolates (DRO17, DRO28, DRO35, and DRO51) were identified by $16 \mathrm{~S}$ rDNA gene sequencing. The $16 \mathrm{~S}$ rRNA gene was amplified using universal PCR primers for Pseudomonas spp. The forward primer was $8 \mathrm{~F}\left(5^{\prime}\right.$-AGAGTTTGATCCTGG CTCAG $\left.-3^{\prime}\right)$ and the reverse prime was U1517R $\left(5^{\prime}-\mathrm{AC}\right.$ GG(A/C) TACCTTGTTACGACTT- $3^{\prime}$ ) (Puente et al., 2004; Karnwal, 2017). The extracted bacterial DNA was used for the PCR reaction (Zaheer et al., 2016) performed with some modifications. The PCR product was purified and submitted for commercial sequencing to Chromos Biotech, Bangalore, India. Bacterial isolate sequences were subjected to alignment with the GENBANK Database for the available type strain sequence. The 16S rRNA gene sequences of DRO17, DRO28, DRO35, and DRO51 Pseudomonas sp. were deposited in the GenBank database with accession numbers MT912759, MT912755, MT912752, and MT912756, respectively.

The multiple sequence alignment algorithm MUSCLE was used with the bacterial strains and aligned with sequences obtained from the BLAST search. The MEGA X program (Parameters: Kimura 2-parameter substitution model and UPGMA statistical method) was used for constructing the phylogenetic tree. The sequence of Escherichia coli was used as an outgroup (Karnwal, 2020).

\section{Results and discussion}

\section{Isolation of root-associated bacteria and screening for ACC deaminase activity}

Unfavourable climatic conditions contribute to a substantial loss in plant growth and yield under the current global climate change (Kumar and Verma, 2018; Ashraf et al., 2019; Badr et al., 2020; Danish et al., 2020). The production of new crop variants for managing abiotic stress is one of the best-used strategies for crop production. However, transgenic techniques and molecular breeding are laborious and costly. The use of PGPRs may work as an alternative strategy to boost stress resistance in crops and is now gaining widespread popula- rity (Praveen Kumar et al., 2014; Timmusk et al., 2018; Karnwal, 2019, Sukmawati et al., 2020). Among the specific PGPR genera, Bacillus and Pseudomonas are the most widely studied rhizobacteria that support seed production and crop development (Timmusk et al., 2018). Previous studies (Danish et al., 2020; Lee et al., 2016; Paterson et al., 2016) have documented multiple strains of Pseudomonas, viz. Pseudomonas fluorescence, Pseudomonas aeruginosa, Pseudomonas putida, Pseudomonas taiwanensis, and Pseudomonas chlororaphis, as wellknown inhabitants of the rhizosphere of several plants such as rice, tomato, wheat, maize, and potato, with plant growth-promoting activities. In the present study, a total of 56 bacterial strains were isolated on King's B agar from rice roots and rhizospheric soil samples obtained from 40 healthy rice plants from Dehradun, Uttarakhand, India. The isolates were designated as DRO1 to DRO56. All the isolates were preserved at $-20^{\circ} \mathrm{C}$ as $30 \%$ glycerol stocks and regularly revived for further analysis.

The protective microbiota linked with the roots and tissues of plants mitigates biotic and abiotic stress through several pathways. Many PGPR have been shown to mitigate the drought effects in plants by declining the amount of plant ethylene (Ahmad et al., 2011; Armada et al., 2016; Amna et al., 2020), which is usually elevated under unfavourable environments. Interestingly, the plant ethylene precursor ACC is cleaved by PGP bacteria synthesizing the ACC deaminase enzyme (ACCd), thus reducing ethylene concentrations in stressed plants (Saleem et al., 2007; Anandham et al., 2008; Rojas-Tapias et al., 2012). In our study, out of 56 isolates, 27 bacterial strains were grown on DF salts minimal agar medium supplemented with $3 \mathrm{mM} \mathrm{ACC}$ as the sole nitrogen source, which confirmed the ACC deaminase activity of the strains (Table1). Under drought stress $(-0.30 \mathrm{MPa})$, only seven bacterial strains DRO2, DRO13, DRO17, DRO28, DRO35, DRO43, and DRO51 showed positive ACC deaminase activity and thus were selected for further analysis (Table 1). Further, all the seven isolates showed variation in ACC deaminase activity as determined quantitatively (from 432 to $1205 \mathrm{nmol} / \mathrm{mg}$ a-ketobutyrate per of cellular protein/h). The maximum ACC deaminase activity was shown by DRO51 (1205 nmol/mg $\alpha$-ketobutyrate cellular protein $h$ ) followed by DRO28 (1064 nmol/mg $\alpha$-ketobutyrate cellular protein/h), DRO35 (998 nmol/mg $\alpha$-ketobutyrate cellular protein/h), and 
Table 1. Bacterial isolates showing ACC deaminase activity under normal and drought conditions

\begin{tabular}{|c|c|c|}
\hline \multirow{2}{*}{$\begin{array}{l}\text { Number } \\
\text { of isolate }\end{array}$} & \multicolumn{2}{|c|}{ ACC deaminase activity results } \\
\hline & under normal condition & under drought stress \\
\hline DRO1 & $+\mathrm{ve}$ & $-\mathrm{ve}$ \\
\hline DRO2 & $+\mathrm{ve}$ & $+\mathrm{ve}$ \\
\hline DRO4 & $+\mathrm{ve}$ & $-\mathrm{ve}$ \\
\hline DRO6 & $+\mathrm{ve}$ & $-\mathrm{ve}$ \\
\hline DRO9 & $+\mathrm{ve}$ & $-\mathrm{ve}$ \\
\hline DRO11 & $+\mathrm{ve}$ & $-\mathrm{ve}$ \\
\hline DRO12 & $+\mathrm{ve}$ & $-\mathrm{ve}$ \\
\hline DRO13 & $+\mathrm{ve}$ & $+\mathrm{ve}$ \\
\hline DRO15 & $+\mathrm{ve}$ & $-\mathrm{ve}$ \\
\hline DRO17 & $+\mathrm{ve}$ & $+\mathrm{ve}$ \\
\hline DRO19 & $+\mathrm{ve}$ & $-\mathrm{ve}$ \\
\hline $\mathrm{DRO} 21$ & $+\mathrm{ve}$ & $-\mathrm{ve}$ \\
\hline $\mathrm{DRO} 22$ & $+\mathrm{ve}$ & $-\mathrm{ve}$ \\
\hline $\mathrm{DRO} 25$ & $+\mathrm{ve}$ & $-\mathrm{ve}$ \\
\hline $\mathrm{DRO} 26$ & $+\mathrm{ve}$ & $-\mathrm{ve}$ \\
\hline DRO27 & $+\mathrm{ve}$ & $-\mathrm{ve}$ \\
\hline $\mathrm{DRO} 28$ & $+\mathrm{ve}$ & $+\mathrm{ve}$ \\
\hline DRO32 & $+\mathrm{ve}$ & $-\mathrm{ve}$ \\
\hline DRO35 & $+\mathrm{ve}$ & $+\mathrm{ve}$ \\
\hline DRO38 & $+\mathrm{ve}$ & $-\mathrm{ve}$ \\
\hline DRO39 & $+\mathrm{ve}$ & $-\mathrm{ve}$ \\
\hline DRO40 & $+\mathrm{ve}$ & $-\mathrm{ve}$ \\
\hline DRO43 & $+\mathrm{ve}$ & $+\mathrm{ve}$ \\
\hline DRO46 & $+\mathrm{ve}$ & $-\mathrm{ve}$ \\
\hline DRO51 & $+\mathrm{ve}$ & $+\mathrm{ve}$ \\
\hline DRO52 & $+\mathrm{ve}$ & $-\mathrm{ve}$ \\
\hline DRO56 & $+\mathrm{ve}$ & $-\mathrm{ve}$ \\
\hline
\end{tabular}

DRO17 (896 nmol $\alpha$-ketobutyrate mg protein/h), DRO43 (772 nmol/mg $\alpha$-ketobutyrate cellular protein/h), DRO13 (518 nmol/mg $\alpha$-ketobutyrate cellular protein/h), and DRO2 $(423 \mathrm{nmol} / \mathrm{mg} \alpha$-ketobutyrate cellular protein $/ \mathrm{h})$ - Figure 1.

Previous studies (Badr et al., 2020; Singh et al., 2015; Veronese et al., 2003) demonstrated the survival and colonization potential of PGPR in the rhizosphere during drought conditions. They reported that the inoculation of PGPR under drought condition improves plant growth and yield. The inoculation with indigenous

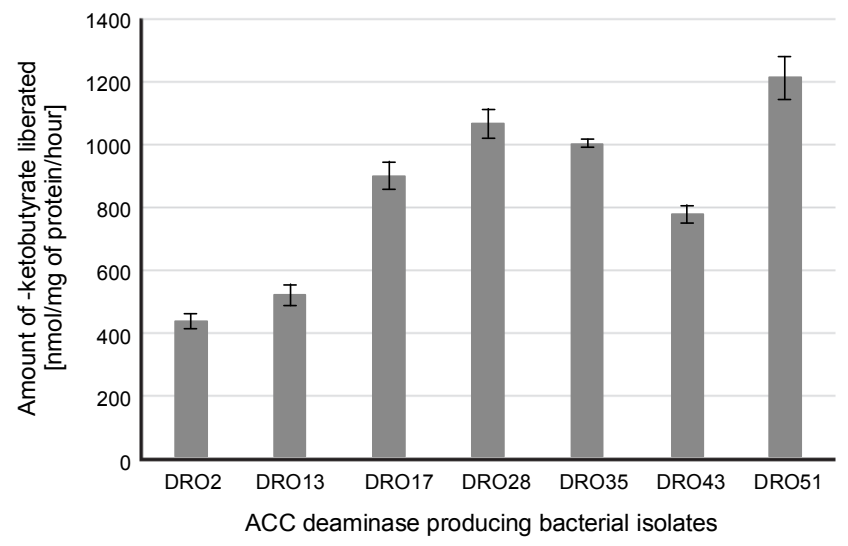

Fig. 1. Quantitative estimation of ACC deaminase activity in terms of $\alpha$-ketobutyrate released (nmol/mg of protein/h)

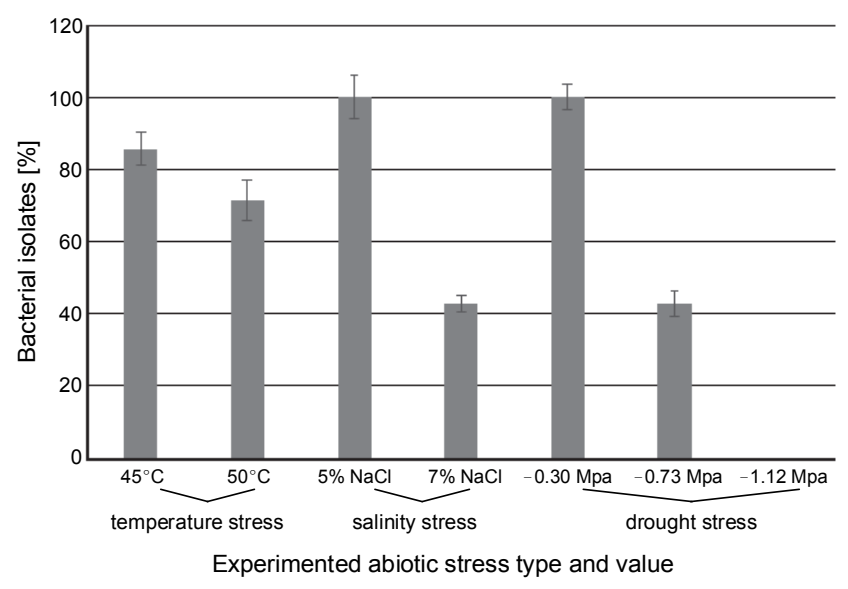

Fig. 2. Abiotic stress tolerance for seven bacterial isolates with positive results for different abiotic stresses (\% bacterial isolate represents the number of bacterial isolates out of the 7 isolates that showed positive results to the tested abiotic stresses)

microorganisms (endophytes), on the other hand, did not improve the growth of plants under drought conditions and resulted in their death due to stress. Therefore, the application of drought-tolerant rhizobacteria can be more useful than other indigenous microorganisms for plant development and yield under drought stress (Danish et al., 2020).

\section{Abiotic stress tolerance of PGPR}

PGPR have been used successfully to improve abiotic stress tolerance in many plants. A variety of abiotic variables (i.e.salinity, soil $\mathrm{pH}$, and elevated temperature) affect the survival and colonization of microbial inoculants in rhizosphere (Armada et al., 2016; Soda et al., 2016). In the present study, all seven ACC deaminaseproducing isolates (under drought condition) were examined for their potential to withstand elevated tempera- 
Table 2. List of Pseudomonas strains and results for the tested abiotic stress

\begin{tabular}{|c|c|c|c|}
\hline \multicolumn{2}{|c|}{ Abiotic stress } & Tolerance to stress & Sensitive to stress \\
\hline \multirow{2}{*}{ Temperature } & $45^{\circ} \mathrm{C}$ & DRO2, DRO17, DRO28, DRO35, DRO43, DRO51 & DRO13 \\
\hline & $50^{\circ} \mathrm{C}$ & DRO2, DRO17, DRO28, DRO35, DRO51 & DRO13, DRO43 \\
\hline \multirow{2}{*}{ Salinity } & $5 \% \mathrm{NaCl}$ & DRO2, DRO13, DRO17, DRO28, DRO35, DRO43, DRO51 & none \\
\hline & $7 \% \mathrm{NaCl}$ & DRO2, DRO13, DRO28 & DRO17, DRO35, DRO43, DRO51 \\
\hline \multirow{3}{*}{ Drought stress } & $-0.30 \mathrm{MPa}$ & DRO2, DRO13, DRO17, DRO28, DRO35, DRO43, DRO51 & none \\
\hline & $-0.73 \mathrm{MPa}$ & DRO17, DRO28, DRO51 & DRO2, DRO13, DRO35, DRO43 \\
\hline & $-1.12 \mathrm{MPa}$ & none & $\begin{array}{l}\text { DRO2, DRO13, DRO17, DRO28, } \\
\text { DRO35, DRO43, DRO51 }\end{array}$ \\
\hline
\end{tabular}

Table 3. Antagonistic activity of Pseudomonas isolates against fungal pathogens by using dual culture and bangle approach

\begin{tabular}{|c|c|c|c|c|c|c|}
\hline $\begin{array}{l}\text { Bacterial } \\
\text { strain }\end{array}$ & $\begin{array}{c}\text { Bipolaris } \\
\text { hawaiiensis } \\
2445\end{array}$ & $\begin{array}{c}\text { Rhizoctonia } \\
\text { solani } \\
4633\end{array}$ & $\begin{array}{c}\text { Curvularia } \\
\text { lunata } \\
350\end{array}$ & $\begin{array}{c}\text { Fusarium } \\
\text { moniliforme } \\
4223\end{array}$ & $\begin{array}{c}\text { Alternaria } \\
\text { padwickii } \\
4122\end{array}$ & $\begin{array}{c}\text { Sclerotium } \\
\text { oryzae } \\
3821\end{array}$ \\
\hline DRO17 & $-(0)^{*}$ & $++(36)$ & $++(31)$ & $-(0)$ & $-(0)$ & $-(0)$ \\
\hline DRO28 & $+(22.4)$ & $-(0)$ & $-(0)$ & $+++(72.5)$ & $+(16.4)$ & $-(0)$ \\
\hline DRO35 & $++(23)$ & $+++(64.3)$ & $++(27)$ & $++(48)$ & $-(0)$ & $++(27.5)$ \\
\hline DRO51 & $++(38.2)$ & $-(0)$ & $-(0)$ & $++(41.2)$ & $+(26)$ & $-(0)$ \\
\hline
\end{tabular}

(-) - no, + - weak, ++ - intermediate, +++ - strong inhibition zone, * numbers in () show results of \% inhibition assessed through the bangle method

tures $\left(45\right.$ and $\left.50^{\circ} \mathrm{C}\right)$, salinity $(5 \%$ and $7 \% \mathrm{NaCl})$, and drought stress $(-0.30,-0.73$, and $-1.12 \mathrm{MPa})$. Out of 7 isolates, six (DRO2, DRO17, DRO28, DRO35, DRO43, and DRO51) tolerated temperature of $45^{\circ} \mathrm{C}$ (Fig. 2), whereas only five strains (DRO2, DRO17, DRO28, DRO35, and DRO51) showed growth at $50^{\circ} \mathrm{C}$ after $48 \mathrm{~h}$ of incubation (Table 2). Additionally, our results provided insight into the effect of salinity on bacterial growth. At $5 \% \mathrm{NaCl}$ concentration, all seven bacterial isolates grew well (Fig. 2), but at higher salt concentration (7\%), bacterial strains DRO2, DRO13, and DRO28 failed to grow. These results suggest that bacterial strains DRO17, DRO35, DRO43, and DRO51 can tolerate high salinity levels $(7 \% \mathrm{NaCl})$ under laboratory conditions (Table 2). Previously, Abd El-Daim et al. (2019) reported that Bacillus velezensis UCMB5113 could enhance wheat tolerance against heat, cold, and drought stress conditions. Heydarian et al. (2016) collected and identified phosphate-solubilizing bacteria resistant to salinity, which grew at $5 \% \mathrm{NaCl}$ concentration. Similarly, the plant growth promotion effects of rhizospheric bacteria $P$. stutzeri, and $P$. aeruginosa on tomatoes were reported by Tank and Saraf (2010) at 6\% saline concentration.
The authors observed that in pot studies in $2 \%$ salt concentration, the bacterial strains $P$. stutzeri $\mathrm{C} 4$ and $P$. aeruginosa 15 improved the growth of tomato plants and were best growth promoters with 50\% enhancement in root and shoot length as compared to NaCl-added untreated plants and plants without $\mathrm{NaCl}$ treatment.

Paul et al. (2006) demonstrated the effect of novel proteins (flagellar M-ring protein, acyl-Coa dehydrogenase oxidoreductase protein, methionyl-tRNA synthetase protein, probable acyl carrier protein, survival protein SurE PA3625, and heat shock protein 60 ) produced by $P$. fluorescence strain MSP-393 which nullified the elevated osmolarity adverse effects on plants. Mhamdi et al. (2015) reported the saprophytic potential and competition of rhizobial isolates with other rhizospheric microorganisms as an essential factor responsible for saline stress tolerance in plants.

Drought stress is one of the most disruptive abiotic stresses occurring worldwide in recent years that influences food supply (Rojas-Tapias et al., 2012; Paterson et al., 2016). Earlier reports have documented the loss of crop yield due to high temperature ( $42 \%$ in maize, $31 \%$ in wheat, and $50 \%$ loss in rice) and drought stress 
(63-87\% in maize, $57 \%$ wheat, $53-92 \%$ rice, $45-69 \%$ chickpea, and $46-71 \%$ soybean) in different crops (Denslow et al., 2007; Borges et al., 2014; Armada et al., 2016; Badr et al., 2020; Danish et al., 2020). Millions of microorganisms inhabit plant roots and create diverse ecological ecosystems that affect plant development and sustainability through biochemical behaviour and interaction with plants (Patel et al., 2018). Throughout the present study, it was observed that the isolated Pseudomonas strains showed more prominent tolerance to drought stress than to temperature and salinity stress. In the present study, seven ACC deaminase-producing bacteria isolates were screened for drought stress tolerance $(-0.30,-0.73$, and $-1.12 \mathrm{MPa})$ by using $\mathrm{PEG}$ 6000. All the tested isolates (DRO2, DRO13, DRO17, DRO28, DRO35, DRO43, and DRO51) could grow at the minimum water potential $(-0.30 \mathrm{MPa})$ as shown in Table 2. It was observed that at higher PEG level $(-0.73 \mathrm{Mpa})$, the optical density of bacterial culture decreased due to increased osmotic stress, and only three isolates (DRO17, DRO28, and DRO51) maintained a similar cell density $\left(10^{8} \mathrm{CFU} / \mathrm{ml}\right)$ as observed at -0.30 MPa stress conditions (Fig. 2 and Fig. 3). It was observed that at the higher PEG level $(-1.12 \mathrm{MPa})$, none of the bacterial isolates maintained its cell density, and no growth was observed, as shown in Figure 3.

Rehman and Nautiyal (2002) reported that the drought-tolerant strain Rhizobium sp. NBRI2505 sesbania withstood $45 \%$ of PEG stress conditions. Timmusk et al. (2018) found that inoculation of Arabidopsis thaliana with Paenibacillus polymyxa increased water stress tolerance potential by improving the expression of the Erd15 gene responsible for the production of protein (ERD-15: early responsive to dehydration 15) that functions as a negative regulator of $\mathrm{ABA}$ responses, including resistance to drought and freezing and stomatal closure regulation. One of the main pathways to exert tolerance to drought stress in rhizospheric bacteria is the production of exopolysaccharides (EPSs). The production of EPSs plays a key role in soil aggregation, thereby increasing the fertility and water holding capacity of the soil (Singh et al., 2015; Paterson et al., 2016; Karnwal, 2019).

\section{In vitro antagonistic activity} against fungal phytopathogens

To improve agricultural productivity, it is necessary to use agrochemicals, but these chemicals exert many adverse side effects on plants, such as chlorosis, leaf necrosis, vein discoloration, and terminal bud death (Parween et al., 2016; Patibanda and Ranganathswamy, 2018; Xia et al., 2019), and on humans, such as stinging eyes, rashes, blisters, blindness, nausea, dizziness, diarrhoea, and death (Halstead et al., 2018). The exposure of crops to pathogens also results in significant crop losses, i.e. $10-50 \%$ in wheat (Wang et al., 2014), 25-41\% in rice (Liu et al., 2014), $20-41 \%$ in maize, $11-32 \%$ in soybean, and $8-21 \%$ in potato (Savary et al., 2019; Sukmawati et al., 2020). Globally, crop production is also reduced by biotic (phytopathogens) stresses. Of these, plant diseases are the most important limiting factors of crop production as different pathogens infect crops, leading to severe losses in yield and quality. Crops can be infected by biotrophic fungi, necrophytic species, and nematodes as well as by viruses and bacteria. Among these, different fungal diseases are the most prominent ones and pose a great challenge to various crops (Goyal and Prasad, 2010; Xu et al., 2018). The most abundant and widespread phytopathogens belong to the genera Magnaporthe spp., Botrytis spp., Puccinia spp., Rhizoctonia spp., Culvularia spp., Pythium spp., Fusarium spp., Blumeria spp., Mycosphaerella spp., Colletotrichum spp., Sclerotium spp., Ustilago spp., Melampsora spp., Alternaria spp., and Arthrinium spp. (Goyal and Prasad, 2010; Liu et al., 2014; Jighly et al., 2016; Sukmawati et al., 2020). Jighly et al. (2016) reported that in natural environment, higher amount of precipitation increased the infection of grains with Fusarium. Seven species of Fusarium were identified in the maize grain samples, namely $F$. avenaceum, $F$. poae, $F$. moniliforme, $F$. graminearum, $F$. culmorum, $F$. acuminatum, $F$. sporotrichioides, and $F$. tricinctum, which cause yield loss in maize (Jighly et al., 2016; Bankina et al., 2017).

Bacillus and Pseudomonas species are often applied as biocontrol agents because they secrete cell wall-degrading enzymes, ironchelators, and various cyclic lipodepsipeptides (CLPs) (El-Reedy and Soliman, 2020; Ashraf et al., 2019). Pseudomonas species secrete a wide range of antimicrobial compounds such as 2, 4-diacetylphloroglucinol, pyoluteorin, pyrrolnitrin, and hydrogen cyanide (Paul et al., 2006; Akter et al., 2016). In the present study, the antifungal potential of the bacterial isolates (DRO17, DRO28, DRO35, and DRO51) was examined against fungal phytopathogens using the dual-culture technique, and weak to strong zones of inhibition 
A

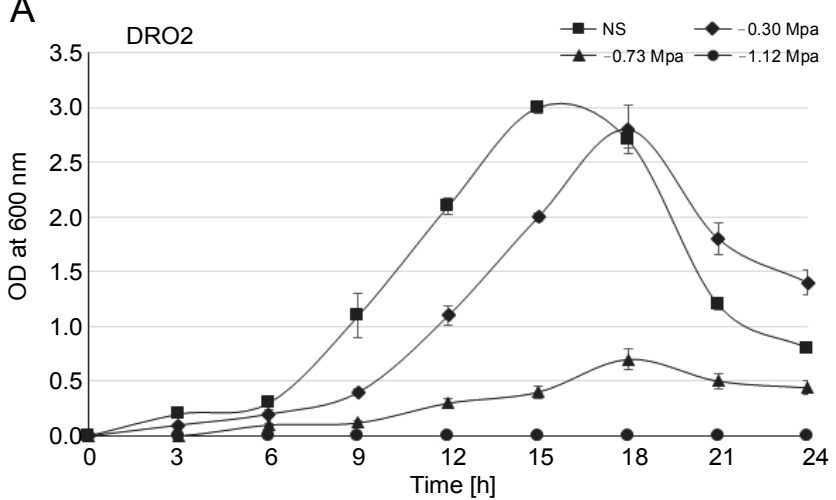

C

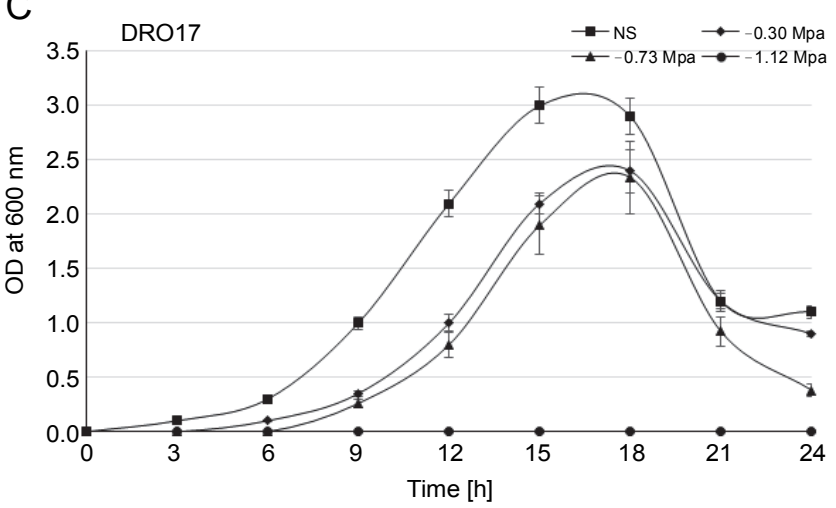

E
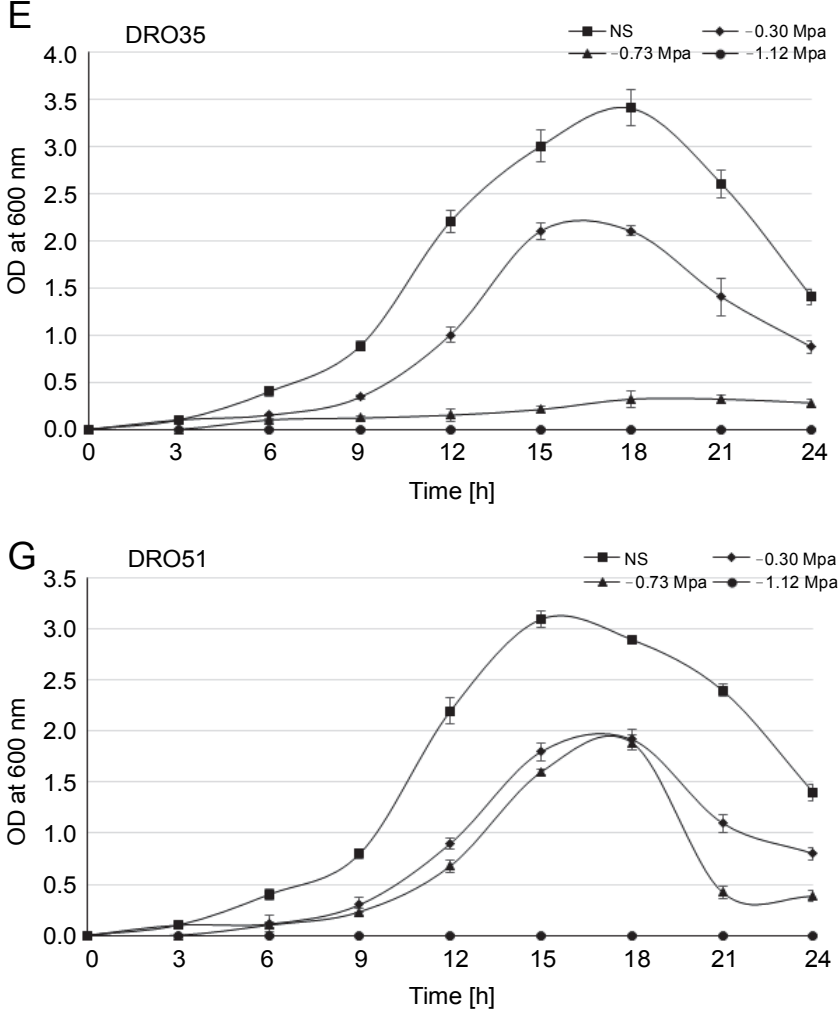

were recorded as mentioned in Table 3 . Out of the 4 selected Pseudomonas isolates (DRO17, DRO28, DRO35, and DRO51), DRO35 successfully inhibited the growth of the fungal pathogens Bipolaris hawaiiensis 2445,
B

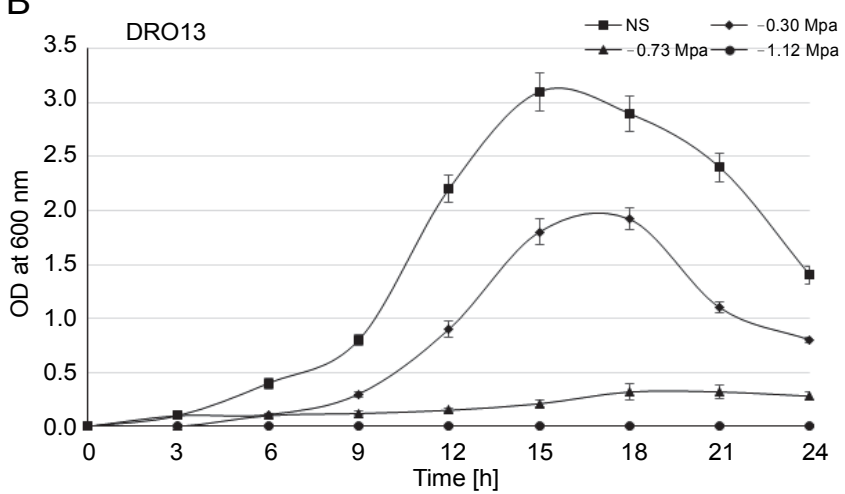

D

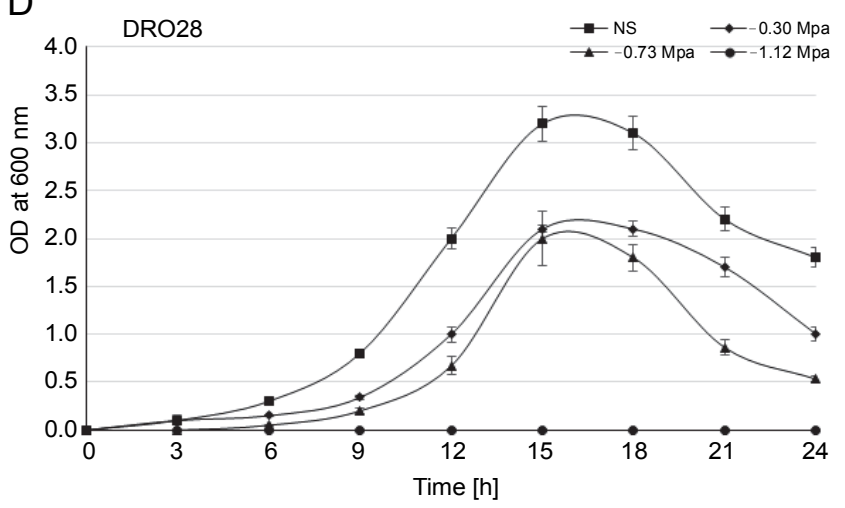

$\mathrm{F}$

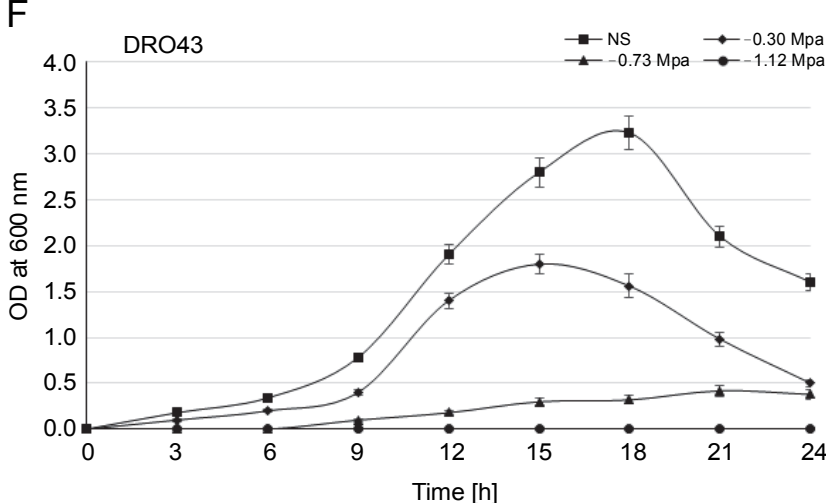

Fig. 3. Growth patterns of the seven Pseudomonas strains isolated from rice rhizosphere under different droughtstressed conditions; NS - nonstressed; error bars show standard deviations of mean values

Rhizoctonia solani 4633, Curvularia lunata 350, Fusarium moniliforme 4223, and Sclerotium oryzae 3821 with $18,32,20,25$, and $22 \mathrm{~mm}$ inhibition zones, respectively, which varied from intermediate to strong in- 
Table 4. Microscopic and biochemical characterization of the isolated Pseudomonas strains

\begin{tabular}{c|c|c|c|c|c|c|c|c|c}
\hline $\begin{array}{c}\text { Bacterial } \\
\text { isolate }\end{array}$ & Shape & $\begin{array}{c}\text { Gram } \\
\text { stain }\end{array}$ & Spore & Motile & Catalase & Oxidase & OF & Citrate & Indole \\
\hline DR017 & Rod & - ve & - & + & + & + & - & - & + \\
\hline DRO28 & Rod & - ve & - & + & + & + & + & - & + \\
\hline DRO35 & Rod & - ve & - & + & + & + & - & - & + \\
\hline DR051 & Rod & - ve & - & + & + & + & - & - & + \\
\hline \hline $\begin{array}{c}\text { Bacterial } \\
\text { isolate }\end{array}$ & Urease & $\begin{array}{c}\text { Nitrate } \\
\text { reduction }\end{array}$ & $\mathrm{H}_{2} \mathrm{~S}$ & Gelatinase & HCN & $\begin{array}{c}\text { Starch } \\
\text { hydrolysis }\end{array}$ & Lipolysis & $\begin{array}{c}\text { Casein } \\
\text { hydrolysis }\end{array}$ \\
\hline DRO17 & - & + & + & + & + & + & + & - \\
\hline DRO28 & - & - & + & - & + & - & - & - \\
\hline DRO35 & - & + & + & + & + & + & - & - \\
\hline DRO51 & - & - & + & - & + & - & - & - \\
\hline
\end{tabular}

hibition. Two isolates (DRO28 and DRO51) inhibited the growth of Bipolaris hawaiiensis 2445 (16 and $24 \mathrm{~mm}$, respectively), Fusarium moniliforme 4223 (44 and $26 \mathrm{~mm}$, respectively), and Alternaria padwickii 4122 (12 and $16 \mathrm{~mm}$, respectively). The results of the dual culture study showed the antifungal potential of DRO17 against Rhizoctonia solani 4633, and Curvularia lunata 350 with 22 and $20 \mathrm{~mm}$ zones of inhibition, respectively (Table 3 ). Members of the Pseudomonas genus are known to synthesize a large number of metabolites, including those that directly stimulate plant growth or those that inhibit the growth of harmful microorganisms [(iron chelators (siderophore), VOCs, antibiotics, molecules that destroy the cell wall, extracellular chitinase, and protease)] (Bankina et al., 2017; Amna et al., 2020). ElSayed et al. (2014) reported the effectiveness of PGPR (Bacillus, Enterobacter, and Pseudomonas) against the fungal phytopathogens Fusarium oxysporum f. sp. lycopersici, and Sclerotinia sclerotiorum that cause diseases in different crops such as the application of Bacillus amyloliquefaciens subsp. plantarum XH-9, a plant-beneficial rhizobacterium, that showed good antagonistic potential against phytopathogens ( $F$. oxysporum, $B$. sorokiniana, and $R$. solanı) of wheat by releasing diffusible and volatile antibiotics and secreting hydrolytic enzymes. The authors reported the effect of antagonistic compounds (diffusible volatile metabolites) produced by PGPR that efficiently reduced the growth of $F$. oxysporum to 6.59 and $47.07 \%$, respectively, and the grown of $R$. solani to 14.29 and $54.29 \%$, respectively. Want et al. (2019) evaluated the antifungal potential on of Paeni- bacillus jamilae HS-26 isolated from cucumber rhizosphere against eight different fungal phytopathogens (Fusarium oxysporum, Botryosphaeria ribis, Bipolaris sorokiniana, Botryosphaeria dothidea, Alternaria(Nees), Fusarium pseudograminearum, Colletotrichum gloeosporioides, and Rhizoctonia solani). The authors observed that the extracellular antifungal metabolites completely inhibited the growth of $B$. sorokiniana and $R$. solani, while that of $F$. oxysporum was reduced by $17.65 \%$ compared to the growth of control. Similar to the extracellular antifungal metabolites, the VOCs produced by the strain HS-26 also reduced the mycelial growth, with the inhibition of $F$. oxysporum, $B$. sorokiniana, and $R$. solani being approximately $46.30,63.86$, and $44 \%$, respectively. Bacillus amyloliquefaciens strain BLB369, Bacillus subtilis strain BLB277, and Paenibacillus polymyxa strain BLB267 were reported to produce iturin and surfactin, surfactin and fengycin, and fusaricidin and polymyxin, respectively, broad-spectrum antifungal compounds that are effective against various phytopathogenic fungi (Zalila-Kolsi et al., 2016) of Tunisian durum wheat (Triticum turgidum L. subsp. durum) cultivar Om Rabiia. Strains BLB369, BLB277, and BLB267 were tested against $F$. graminearum (ISPAVE 271), $F$. oxysporum (CTM10402), F. culmorum (ISPAVE 21w), Alternaria alternata (CTM10230), Rhizoctonia oryzae, and Aspergillus niger. The authors reported that the synergistic effect of all the three bacterial isolates showed the highest protection rate against $F$. graminearum (ISPAVE 271), $F$. oxysporum (CTM10402), and $F$. culmorum (ISPAVE 21w) (Zalila-Kolsi et al., 2016). Ban- 
A $\quad$ NR 114476.1 Pseudomonas fluorescens strain ATCC 13525
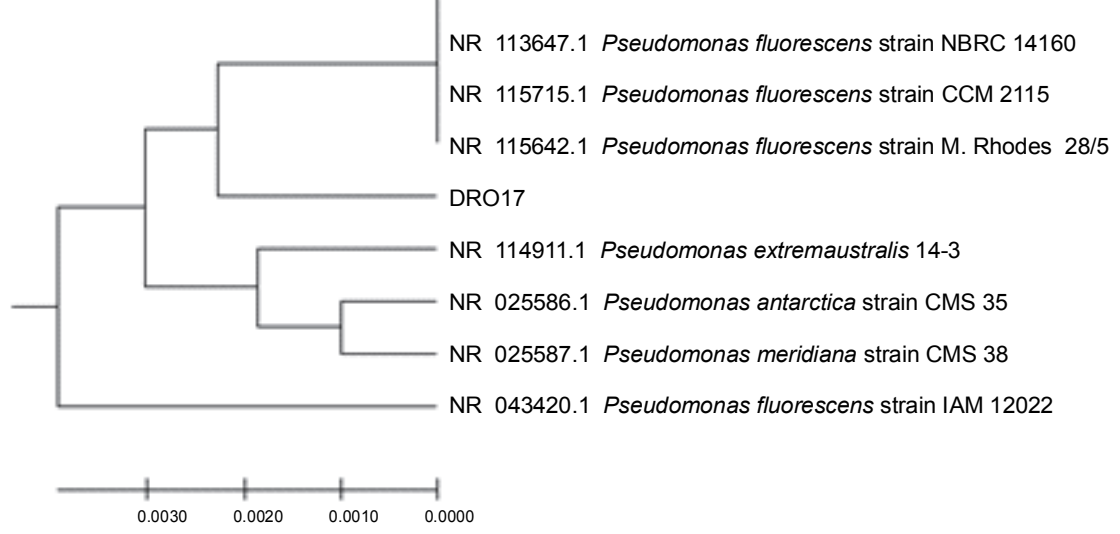

B

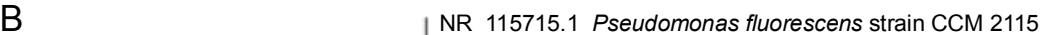
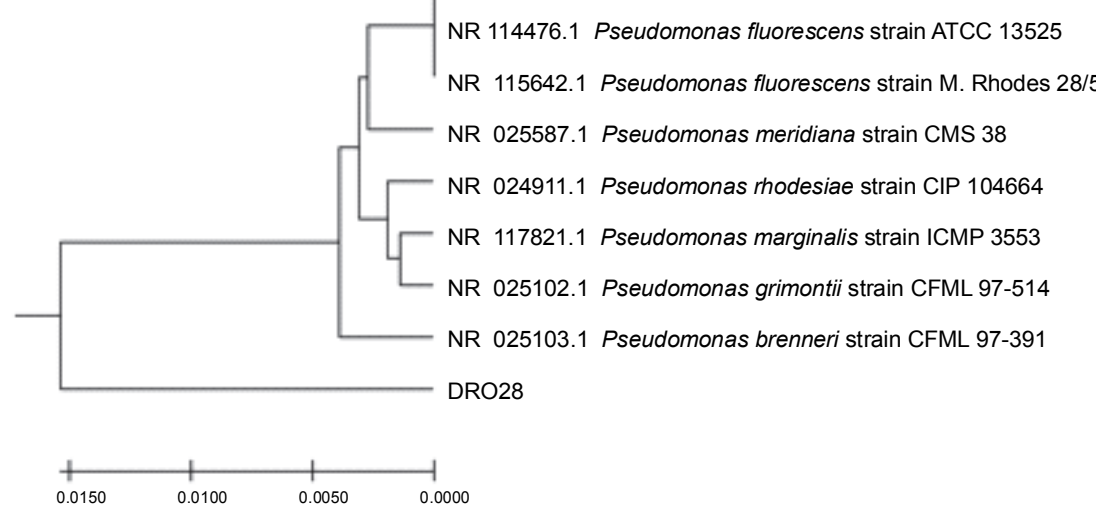

C

NR 115642.1 Pseudomonas fluorescens strain M. Rhodes 28/5

NR 114476.1 Pseudomonas fluorescens strain ATCC 13525

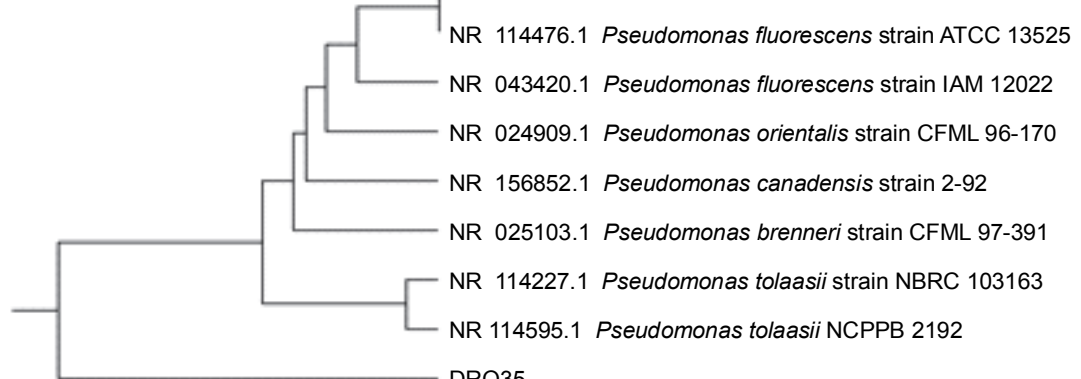
DRO35

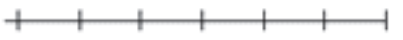

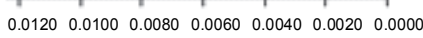

$\mathrm{D}$
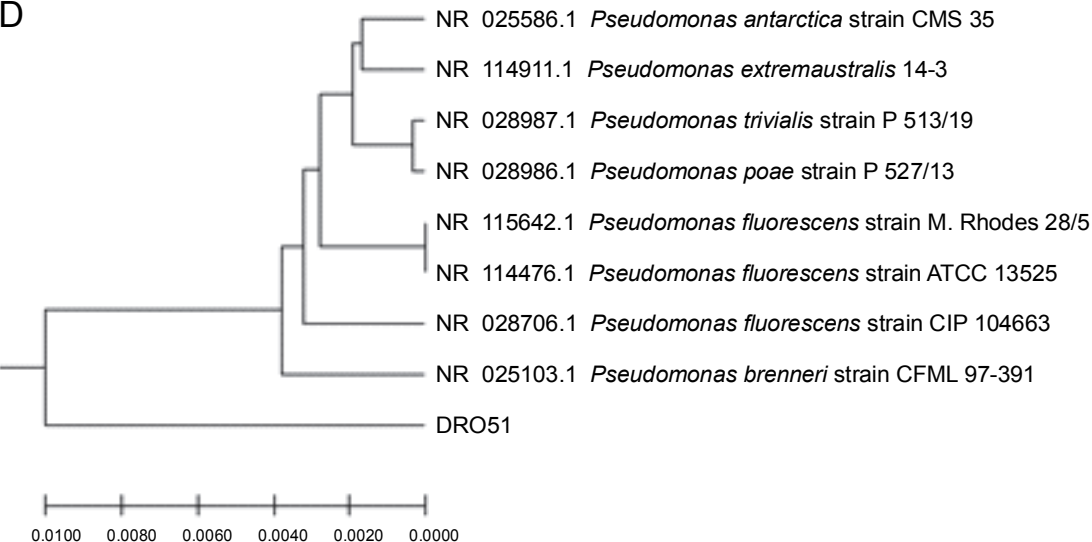

Fig. 4. The evolutionary tree of the bacterial isolates A) DRO17, B) DRO28, C) DRO35, and D) DRO51generated with MEGA X software 
kina et al. (2017) reported that the strains of the species Pseudomonas fluorescens are biocontrol agents and include $P$. fluorescens A506 and P. fluorescens EPS62e that are effective against Erwinia amylovora. Antagonistic organisms often produce secondary metabolites with antimicrobial potency and can also promote plant growth (Amna et al., 2020). Antagonistic bacteria investigated to date have been mostly isolated from rhizosphere soils and include species of Bacillus, Streptomyces, and Pseudomonas (Paterson et al., 2016). These antagonistic bacterial species are mostly considered safe and can synthesize beneficial substances (Tank and Saraf, 2010).

Further analysis of the antifungal activity using the bangle approach indicated that DRO35 was strongly antagonistic towards Rhizoctonia solani 4633, followed by Fusarium moniliforme 4223, and showed inhibition of 64.3 and 48\%, respectively (Table 3). DRO35 also showed positive antagonistic results with 23,27 , and 27.5\% inhibition for Bipolaris hawaiiensis 2445, Curvularia lunata 350 , and Sclerotium oryzae 3821 , respectively. DRO28 was effective with inhibition of $72.5 \%$, and DRO51 showed $41.2 \%$ inhibition of Fusarium moniliforme 4223. DRO51 was the best isolate to inhibit the growth of Bipolaris hawaiiensis 2445, with $38.2 \%$ inhibition, and DRO28 was the next best isolate with $22.4 \%$. DRO17 reduced the growth of Rhizoctonia solani 4633 and Curvularia lunata 350 by 36 and 31\%, respectively (Table 3). These study results were in agreement with the other studies conducted by Lee et al. (2006), Akter et al. (2016), Patel et al. (2018), and El-Reedy and Soliman (2020), thus showing that Pseudomonads form the largest community of nondifferentiating microorganisms that excrete antimicrobial compounds such as phycocyanin, pyrrolnitrin, and pseudomonic acid (Akter et al., 2016; El-Reedy and Soliman, 2020).

\section{Identification and characterization of the chosen bacterial strains}

Plants have evolved with an abundance of microorganisms having important roles for plant growth and health. The microbial component of the plant holobiont, also termed as plant microbiota (comprising all microorganisms) or the plant microbiome (comprising all microbial genomes), in the rhizosphere, phyllosphere, and endosphere has essential functions supporting plant growth and health. Plants with their root system provide unique ecological niches for soil microbiota, which colonize the rhizosphere, roots, and to a certain extent, the above-ground parts of plants (Gontia-Mishra et al., 2016; Danish et al., 2020). Beneficial plant-microbe associations are an interdependent relationship wherein plants and microorganisms provide benefits to each other and can be grouped under two major categories of relationship: direct and indirect (Karnwal, 2019; Danish et al., 2020). In the present study, the isolates DRO17, DRO28, DRO35, and DRO51 were examined for their morphological and biochemical traits. Morphologically, the isolates DRO17, DRO28, DRO35, and DRO51 were rod-shaped and gram-negative, motile, and nonspore formers. It was observed that all the four isolates (DRO17, DRO28, DRO35, and DRO51) were catalase-positive, oxidase-positive, and could produce $\mathrm{H}_{2} \mathrm{~S}$, indole, and $\mathrm{HCN}$. The DRO17 and DRO35 isolates showed positive results for starch hydrolysis and gelatine liquefaction. All the four bacterial isolates (DRO17, DRO28, DRO35, and DRO51) were urease- negative, citrate-negative, and could not hydrolyse casein (Table 4).

\section{Molecular identification of the bacterial isolates}

The 16S rRNA gene sequencing method was used for the molecular characterization of the bacterial isolates. BLAST results of DRO17 16s rRNA gene sequence alignment showed $98.2 \%$ identity with Pseudomonas antarctica strain CMS 35, while the DRO28 16S rRNA gene sequence showed $97.23 \%$ identity with Pseudomonas fluorescens strain M. Rhodes 28/5 and Pseudomonas fluorescens strain CCM 2115 (97.23\%). Blast results for DRO35 showed higher similarity with Pseudomonas fluorescens strain ATCC 13525 16S ribosomal RNA, partial sequence (98.12\%), and Pseudomonas fluorescens strain M. Rhodes 28/5 (98.12\%). BLAST results for the bacterial isolate DRO51 16s rRNA gene sequence showed $98.35 \%$ similarity with Pseudomonas fluorescens strain M. Rhodes $28 / 5$ and $97.90 \%$ with Pseudomonas antarctica strain CMS 35. The phylogenetic tree for all the four isolates was prepared by using MEGA X software and is presented in Figure 4.

\section{Conclusions}

The results of this study revealed the natural relationship between rice and a variety of rhizobacteria with abiotic stress tolerance, antifungal activity, and plant growth-promoting properties. Our findings indicate 
that ACC deaminase-producing rice rhizobacteria may reduce drought stress in plants by improving soil structure and bacterial colonization.

The antagonistic effect of rhizosphere microorganisms against plant pathogens leads to the elimination of plant diseases. However, the major difficulty with these microbial agents is inconsistent efficiency when using in fields, which affects the interrelationships between the plants and microbial agents. The effectiveness of these biological agents is also influenced by physical and natural environment, which results in low rhizosphere competence. Thus, this research provides the basis for the best possible selection and application of biological agents with abiotic stress tolerance and confirms antagonistic activity against fungal phytopathogens. In addition, the strains DRO17, DRO28, DRO35, and DRO51 with abiotic stress tolerance and antagonistic activity can be used as eligible bacterial agents for further analysis and formulation as a biofertilizer.

\section{Acknowledgements}

I am very thankful to Doon (PG) Paramedical College \& Hospital, Dehradun, Uttarakhand, and Bhojia Institute of Life Sciences, Budh, Baddi, Himachal Pradesh, India, for technical support to complete this study and unlimited help in all steps.

\section{References}

Abd El-Daim I.A., Bejai S., Meijer J. (2019) Bacillus velezensis 5113 induced metabolic and molecular reprogramming during abiotic stress tolerance in wheat. Sci. Rep. 9(1): 16282.

Ahmad M., Zahir Z.A., Asghar H.N., Asghar M. (2011) Inducing salt tolerance in mung bean through coinoculation with rhizobia and plant-growth-promoting rhizobacteria containing 1-aminocyclopropane-1-carboxylate deaminase. Can. J. Microbiol. 57: 578-589.

Akter S., Kadir J., Juraimi A.S., Saud H.M. (2016) In vitro evaluation of Pseudomonas bacterial isolates from rice phylloplane for biocontrol of Rhizoctonia solani and plant growth promoting traits. J. Environ. Biol. 37(4): 597-602.

Amna Xia Y., Farooq M.A., Javed M.T., Kamran M.A., Mukhtar T., Ali J., Tabassum T., Rehman S.U., Hussain Munis M.F., Sultan T., Chaudhary H.J. (2020) Multi-stress tolerant PGPR Bacillus xiamenensis PM14 activating sugarcane (Saccharum officinarum L.) red rot disease resistance. Plant Physiol. Biochem. 151: 640-649.

Anandham R., Gandhi P.I., Madhaiyan M., Sa T. (2008) Potential plant growth promoting traits and bioacidulation of rock phosphate by thiosulfate oxidizing bacteria isolated from crop plants. J. Basic Microbiol. 48(6): 439-447.

Andreolli M., Zapparoli G., Angelini E., Lucchetta G., Lampis S., Vallini G. (2019) Pseudomonas protegens MP12: a plant growth-promoting endophytic bacterium with broad-spectrum antifungal activity against grapevine phytopathogens. Microbiol. Res. 219: 123-131.

Armada E., Probanza A., Roldan A., Azcon R. (2016) Native plant growth promoting bacteria Bacillus thuringiensis and mixed or individual mycorrhizal species improved drought tolerance and oxidative metabolism in Lavandula dentata plants. J. Plant Physiol. 192: 1-12.

Ashraf A., Bano A., Ali S.A. (2019) Characterisation of plant growth-promoting rhizobacteria from rhizosphere soil of heat-stressed and unstressed wheat and their use as bioinoculant. Plant Biol. 21(4): 762-769.

Badr A., El-Shazly H.H., Tarawneh R.A., Borner A. (2020) Screening for drought tolerance in maize (Zea mays L.) germplasm using germination and seedling traits under simulated drought conditions. Plants 9(5): 565.

Bankina B., Bimšteine G., Neusa-Luca I., Roga A., Fridmanis D. (2017) What influences the composition of fungi in wheat grains? Acta Agrobot. 70(4): 1726.

Borges A.A., Jiménez-Arias D., Expósito-Rodríguez M., Sandalio L.M., Pérez J.A. (2014) Priming crops against biotic and abiotic stresses: $M S B$ as a tool for studying mechanisms. Front. Plant Sci. 5: 642.

Bradford M.M. (1976) A rapid and sensitive method for the quantitation of microgram quantities of protein utilizing the principle of protein-dye binding. Analyt. Biochem. 72: 248-254.

Danish S., Zafar-Ul-Hye M., Mohsin F., Hussain M. (2020) ACC-deaminase producing plant growth promoting rhizobacteria and biochar mitigate adverse effects of drought stress on maize growth. PLoS One 15(4): e0230615.

De Vita P., Taranto F. (2019) Durum wheat (Triticum turgidum ssp. durum) breeding to meet the challenge of climate change. [in:] Advances in Plant Breeding Strategies: Cereals. Springer: 471--524.

Denslow S.A., Rueschhoff E.E., Daub M.E. (2007) Regulation of the Arabidopsis thaliana vitamin B6 biosynthesis genes by abiotic stress. Plant Physiol. Biochem. 45(2): 152-161.

Dworkin M., Foster J. (1958) Experiments with some microorganisms which utilize ethane and hydrogen. J. Bacteriol. 75: 592-601.

El-Reedy A.A.M., Soliman N.K. (2020) Synthesis, biological activity and molecular modeling study of novel 1,2,4-triazolo[4,3-b][1,2,4,5]tetrazines and 1,2,4-triazolo[4,3-b] [1,2,4]triazines. Sci. Rep. 10(1): 6137.

El-Sayed W.S., Akhkha A., El-Naggar M.Y., Elbadry M. (2014) In vitro antagonistic activity, plant growth promoting traits and phylogenetic affiliation of rhizobacteria associated with wild plants grown in arid soil. Front. Microbiol. 5: 651.

Fahad S., Hussain S., Bano A., Saud S., Hassan S., Shan D., Khan F.A., Khan F., Chen Y., Wu C., Tabassum M.A., Chun M.X., Afzal M., Jan A., Jan M.T., Huang J. (2015) Potential role of phytohormones and plant growth-promoting rhizobacteria in abiotic stresses: consequences for changing environment. Environ. Sci. Pollut. Res. 22(7): 4907-4921.

Garg A.K., Kim J.K., Owens T.G., Ranwala A.P., Choi Y.D., Kochian L.V., Wu R.J. (2002) Trehalose accumulation in 
rice plants confers high tolerance levels to different abiotic stresses. Proc. Nat. Acad. Sci. USA 99(25): 15898-15903.

Gontia-Mishra I., Sapre S., Sharma A., Tiwari S. (2016) Amelioration of drought tolerance in wheat by the interaction of plant growth-promoting rhizobacteria. Plant Biol. 18(6): 992-1000.

Goyal A., Prasad R. (2010) 27 Some important fungal diseases and their impact on wheat production. Management of fungal plant pathogens: 362-373.

Grebenikova N., Korshunov A., Savchenko I., Marques M. (2018) Root rot grain crops on Cereals caused by the phytopathogenic fungi. [in:] MATEC Web of Conferences (245): 11006

Halstead N.T., Hoover C.M., Arakala A., Civitello D.J., De Leo G.A., Gambhir M., Johnson S.A., Jouanard N., Loerns K.A., McMahon T.A, Ndione R. A. (2018) Agrochemicals increase risk of human schistosomiasis by supporting higher densities of intermediate hosts. Nature Commun. 9(1): 1-10.

Heydarian Z., Yu M., Gruber M., Glick B.R., Zhou R., Hegedus D.D. (2016) Inoculation of soil with plant growth promoting bacteria producing 1-aminocyclopropane-1-carboxylate deaminase or expression of the corresponding acdS gene in transgenic plants increases salinity tolerance in Camelina sativa. Front. Microbiol. 7: 1966.

Honma M., Shimomura T. (1978) Metabolism of 1-aminocyclopropane-1-carboxylic acid. Agr. Biol. Chem. 42: 1825-1831.

Jadhav H.P., Shaikh S.S., Sayyed R.Z. (2017) Role of hydrolytic enzymes of rhizoflora in biocontrol of fungal phytopathogens: an overview. [in:] Rhizotrophs: Plant growth promotion to bioremediation, Springer, Singapore: 183-203.

Jahromi F., Aroca R., Porcel R., Ruiz-Lozano J.M. (2008) Influence of salinity on the in vitro development of Glomus intraradices and on the in vivo physiological and molecular responses of mycorrhizal lettuce plants. Microb. Ecol. 55(1): 45-53.

Jighly A., Alagu M., Makdis F., Singh M., Singh S., Emebiri L.C., Ogbonnaya F.C. (2016) Genomic regions conferring resistance to multiple fungal pathogens in synthetic hexaploid wheat. Mol. Breed. 36(9): 127.

Kajla M., Yadav V. K., Khokhar J., Singh S., Chhokar R.S., Meena R.P., Sharma R.K. (2015) Increase in wheat production through management of abiotic stresses: a review. J. Appl. Natural Sci. 7(2): 1070-1080.

Karnwal A. (2009) Production of indole acetic acid by fluorescent pseudomonas in the presence of L-tryptophan and rice root exudates. J. Plant Pathol. 19(1): 61-63.

Karnwal A. (2019) Screening, isolation and characterization of culturable stress-tolerant bacterial endophytes associated with Salicornia brachiata and their effect on wheat (Triticum aestivum L.) and maize (Zea mays) growth. J. Plant Protect. Res. 59(3): 293-303.

Karnwal A. (2020) Effect of salt stress-tolerant bacterial endophytes from Bougainvillea glabra on the growth of Triticum aestivum L. var. HD 2687 and Zea mays var. PSCL4642. BioTechnologia. 101(2): 89-99.

Karnwal A., Dohroo A. (2018) Effect of maize root exudates on indole-3-acetic acid production by rice endophytic bacteria under influence of L-tryptophan. F1000Res. 7: 112.
Kekuda P.T.R., Akarsh S., Nawaz N.A.S., Ranjitha M.C., Darshini S.M., Vidya P. (2016) In vitro antifungal activity of some plants against Bipolaris sorokiniana (Sacc.) Shoem. Int. J. Curr. Microbiol. Appl. Sci. 5(6): 331-337.

Khan N., Maymon M., Hirsch A.M. (2017) Combating Fusarium infection using Bacillus-based antimicrobials. Microorganisms 5(4): 75 .

Korejo F., Noreen R., Ali S.A., Humayun F., Rahman A., Sultana V., Ehteshamul-Haque S. (2017) Evaluation of antibacterial and antifungal potential of endophytic fluorescent Pseudomonas associated with Salvadora persica and Salvadora oleoides decne. Pakistan J. Bot. 49(5): 1995-2004.

Krieg N.R., Holt J.G. (1984) Bergey's manual of systematic bacteriology. Williams \& Wilkins, Baltimore, London.

Kumar A., Verma J.P. (2018) Does plant-Microbe interaction confer stress tolerance in plants: A review? Microbiol. Res. 207: 41-52.

Kumar S., Stecher G., Li M., Knyaz C., Tamura K. (2018) MEGA X: Molecular evolutionary genetics analysis across computing platforms. Mol. Biol. Evol. 35: 1547-1549.

Lee S.C., Choi H.W., Hwang I.S., Choi D.S., Hwang B.K. (2006) Functional roles of the pepper pathogen-induced bZIP transcription factor, CAbZIP1, in enhanced resistance to pathogen infection and environmental stresses. Planta 224(5): 1209-1225.

Lee S.K., Lur H.S., Lo K.J., Cheng K.C., Chuang C.C., Tang S.J., Yang Z.W., Liu C.T. (2016) Evaluation of the effects of different liquid inoculant formulations on the survival and plant-growth-promoting efficiency of Rhodopseudomonas palustris strain PS3. Appl. Microbiol. Biotech. 100(18): 7977-7987.

Liu W., Liu J., Triplett L., Leach J.E., Wang G.L. (2014) Novel insights into rice innate immunity against bacterial and fungal pathogens. Ann. Rev. Phytopathol. 52: 213-241.

Mahmood A., Turgay O.C., Farooq M., Hayat R. (2016) Seed biopriming with plant growth promoting rhizobacteria: a review. FEMS Microbiol. Ecol. 92(8). Article id: fiw112.

Mhamdi R., Nouairi I., ben Hammouda T., Mhamdi R., Mhadhbi H. (2015) Growth capacity and biochemical mechanisms involved in rhizobia tolerance to salinity and water deficit. J. Basic Microbiol. 55(4): 451-461.

Parween T., Jan S., Mahmooduzzafar S., Fatma T., Siddiqui Z.H. (2016) Selective effect of pesticides on plant - a review. Crit. Rev. Food Sci. Nutr. 56(1): 160-179.

Patel J.K., Madaan S., Archana G. (2018) Antibiotic producing endophytic Streptomyces spp. colonize above-ground plant parts and promote shoot growth in multiple healthy and pathogen-challenged cereal crops. Microbiol. Res. 215: 36-45.

Paterson J., Jahanshah G., Li Y., Wang Q., Mehnaz S., Gross H. (2016) The contribution of genome mining strategies to the understanding of active principles of PGPR strains. FEMS Microbiol. Ecol. 93(3): fiw249.

Patibanda A.K., Ranganathswamy M. (2018) Effect of agrichemicals on biocontrol agents of plant disease control. [in:] Microorganisms for green revolution. Springer, Singapore.

Paul D., Dineshkumar N., Nair S. (2006) Proteomics of a plant growth-promoting rhizobacterium, Pseudomonas fluores- 
cens MSP-393, subjected to salt shock. World J. Microbiol. Biotech. 22(4): 369-374.

Praveen Kumar G., Mir Hassan Ahmed S.K., Desai S., Leo Daniel Amalraj E., Rasul A. (2014) In vitro screening for abiotic stress tolerance in potent biocontrol and plant growth promoting strains of Pseudomonas and Bacillus spp. Int. J. Bacteriol. 2014: 195946.

Puente M.E., Bashan Y., Li C.Y., Lebsky V.K. (2004) Microbial populations and activities in the rhizoplane of rock-weathering desert plants. I. root colonization and weathering of igneous rocks. Plant Biol. 6(5): 629-642.

Rehman A., Nautiyal C.S. (2002) Effect of drought on the growth and survival of the stress-tolerant bacterium Rhizobium sp. NBRI2505 sesbania and its drought-sensitive transposon Tn 5 mutant. Curr. Microbiol. 45(5): 368-377.

Rojas-Solís D., Zetter-Salmón E., Contreras-Pérez M., del Carmen Rocha-Granados M., Macías-Rodríguez L., Santoyo G. (2018) Pseudomonas stutzeri E25 and Stenotrophomonas maltophilia CR71 endophytes produce antifungal volatile organic compounds and exhibit additive plant growth-promoting effects. Biocatal. Agr. Biotech. 13: 46-52.

Rojas-Tapias D., Moreno-Galván A., Pardo-Díaz S., Obando M., Rivera D., Bonilla R. (2012) Effect of inoculation with plant growth-promoting bacteria (PGPB) on amelioration of saline stress in maize (Zea mays). Appl. Soil Ecol. 61: 264-272.

Rueda-Puente E.O., Murillo-Amador B., Castellanos-Cervantes T., Garcia-Hernandez J.L., Tarazon-Herrera M.A., Moreno Medina S., Gerlach Barrera L.E. (2010) Effects of plant growth promoting bacteria and mycorrhizal on Capsicum annuum L. var. aviculare ([Dierbach] D'Arcy and Eshbaugh) germination under stressing abiotic conditions. Plant Physiol. Biochem. 48(8): 724-730.

Saleem M., Arshad M., Hussain S., Bhatti A.S. (2007) Perspective of plant growth promoting rhizobacteria (PGPR) containing ACC deaminase in stress agriculture. J. Ind. Microbiol. Biotech. 34(10): 635-648.

Savary S., Willocquet L., Pethybridge S.J., Esker P., McRoberts N., Nelson A. (2019) The global burden of pathogens and pestson major food crops. Nature Ecol. Evol. 3(3): 430-439.

Selikhovkin A.V., Markowskaja S., Vasaitis R., Martynov A.N., Musolin D.L. (2018) Phytopathogenic fungus Fusarium circinatum and potential for its transmission in Russia by insects. Russ. J. Biol. Invas. 9(3): 245-252.

Shirsath L.P., Patil S.P., Patil U.K. (2018) Incidence of leaf spot disease on cotton caused by Curvularia verruculosa and role of its hydrolytic enzymes in pathogenesis. Physiol. Mol. Biol. Plants 24(4): 711-714.

Singh R.P., Jha P., Jha P.N. (2015) The plant-growth-promoting bacterium Klebsiella $s p$. SBP-8 confers induced systemic tolerance in wheat (Triticum aestivum) under salt stress. J. Plant Physiol. 184: 57-67.

Soda N., Sharan A., Gupta B.K., Singla-Pareek S.L., Pareek A. (2016) Evidence for nuclear interaction of a cytoskeleton protein (OSIFL) with metallothionein and its role in salinity stress tolerance. Sci. Rep. 6: 34762.

Sukmawati D., Shabrina A., Indrayanti R., Kurniati T.H., Nurjayadi M., Hidayat I., Al Husna S.N., Ratnaningtyas N.I., El Enshasy H., Dailin D.J., Hesham A.E. (2020) Antifungal mechanism of Rhodotorula mucilaginosa and Aureobasidium sp. nov. isolated from Cerbera manghas $L$. against the growth of destructive molds in postharvested apples. Recent Patents Food Nutr. Agr. 11: 1. doi.org: 10.2174/ 2212798411666200423101159.

Tank N., Saraf M. (2010) Salinity-resistant plant growth promoting rhizobacteria ameliorates sodium chloride stress on tomato plants. J. Plant Interact. 5(1): 51-58.

Timmusk S., Seisenbaeva G., Behers L. (2018) Titania (TiO2) nanoparticles enhance the performance of growth-promoting rhizobacteria. Sci. Rep. 8(1): 617.

Tiwari S., Prasad V., Chauhan P.S., Lata C. (2017) Bacillus amyloliquefaciens confers tolerance to various abiotic stresses and modulates plant response to Phytohormones through osmoprotection and gene expression regulation in rice. Front. Plant Sci. 8: 1510.

Veronese P., Narasimhan M.L., Stevenson R.A., Zhu J.K., Weller S.C., Subbarao K.V., Bressan R.A. (2003) Identification of a locus controlling Verticillium disease symptom response in Arabidopsis thaliana. Plant J. 35(5): 574-587.

Volpiano C.G., Lisboa B.B., São José J.F.B., de Oliveira A.M.R., Beneduzi A., Passaglia L.M.P., Vargas L.K. (2018) Rhizobium strains in the biological control of the phytopathogenic fungi Sclerotium (Athelia) rolfsii on the common bean. Plant Soil 432(1-2): 229-243.

Wang S., Huang Z., Wan Q., Feng S., Xie X., Zhang R., Zhang Z. (2020) Comparative genomic and metabolomic analyses of two Pseudomonas aeruginosa strains with different antifungal activities. Front. Microbiol. 11: 1841.

Wang X., Li Q., Sui J., Zhang J., Liu Z., Du J., Xu R., Zhou Y., Liu X. (2019) Isolation and characterization of antagonistic bacteria Paenibacillus jamilae HS-26 and their effects on plant growth. BioMed Res. Int. 2019: 3638926-3638926.

Wang X., Wang C., Li Q., Zhang J., Ji C., Sui J., Liu Z., Song X., Liu X. (2018) Isolation and characterization of antagonistic bacteria with the potential for biocontrol of soil borne wheat diseases. J. Appl. Microbiol. 125(6): 1868-1880.

Wang Y., Zia S., Owusu-Adu S., Gerhards R., Müller J. (2014) Early detection of fungal diseases in winter wheat by multioptical sensors. APCBEE procedia 8: 199-203.

Xia Y., Sahib M.R., Amna A., Opiyo S.O., Zhao Z., Gao Y.G. (2019) Culturable endophytic fungal communities associated with plants in organic and conventional farming systems and their effects on plant growth. Sci. Rep. 9(1): 1-10.

Xu K.G., Jiang Y.M., Li Y.K., Xu Q.Q., Niu J.S., Zhu X.X., Li Q.Y. (2018) Identification and pathogenicity of fungal pathogens causing black point in wheat on the North China plain. Indian J. Microbiol. 58(2): 159-164.

Zaheer A., Mirza B.S., Mclean J.E., Yasmin S., Shah T.M., Malik K.A., Mirza M.S. (2016) Association of plant growthpromoting Serratia spp. with the root nodules of Chickpea. Res. Microbiol. 167(6): 510-520.

Zalila-Kolsi I., Mahmoud A.B., Ali H., Sellami S., Nasfi Z., Tounsi S., Jamoussi K. (2016) Antagonist effects of Bacillus spp. strains against Fusarium graminearum for protection of durum wheat (Triticum turgidum L. subsp. durum). Microbiol. Res. 192: 148-158. 